\title{
ULTRASTRUCTURAL STUDIES ON LYSIS OF BLUE-GREEN ALGAE BY A BACTERIUM
}

\author{
YOKO YAMAMOTO AND KENJI SUZUKI* \\ Faculty of Agriculture, Meiji University, Ikuta, Kawasaki, \\ *The National Institute of Health, Tokyo, Japan
}

(Received February 14, 1977)

\begin{abstract}
Bacteria which lyse blue-green algae were isolated from soil samples collected from Africa and Japan. The characteristics of one of these bacteria (bacterium MY-1) were electron microscopically investigated. The bacterium was an aflagellate, gram-negative rod. The vegetative cells of Anabaena cylindrica were rapidly decomposed by the action of this bacterium MY-1 and only membranous materials, probably fragments of thylakoid, remained. The inner membranes of akinetes and heterocysts were also digested, leaving the outer membrane or envelope intact.
\end{abstract}

Lysis of blue-green algae by bacteria was first reported by SHILo (1). Later these bacteria were identified as members of Myxobacterales (2-10). They produce plaques on lawns of blue-green algae 5-7 days after inoculation. Vegetative cells of algae are easily attacked and disintegrated by the bacteria, but akinetes and heterocysts are more resistant to their action. We found, from soil samples, bacteria capable of lysing akinetes and heterocysts as well as vegetative cells of bluegreen algae. The present paper deals with ultrastructural aspects of lytic processes of Anabaena cylindrica as induced by one of these bacteria. The spectrum of lytic activity of this bacterium is also described.

\section{MATERIALS AND METHODS}

Microorganisms and cultivation. Several strains of bacteria capable of lysing blue-green algae were isolated from soil samples collected from Africa and Japan by the method used in the screening test for cyanophage (11). These bacteria were grown at $30^{\circ}$ on lawns of blue-green algae, which were developed on a soft agar under illumination at 1,000 lux.

Most of the strains of blue-green and other algae (M, C, and E numbers in Table 2) were obtained from the Culture Collection of Algae at the Institute of Applied Microbiology, University of Tokyo. Shizothrix calcicola and Symploca 
muscorum were supplied from the Culture Collection of Algae and Protozoa, Botany School, Cambridge. Some blue-green algae (W numbers) and Navicula zonata were isolated from soil and water samples collected in Japan. Pseudomonas aeruginosa Ps -2 and Ps-8 were kindly supplied by Dr. K. Mise, the Institute of Public Health, Tokyo, and other bacteria were from The Culture Collection of Bacteria at the National Institute of Health, Tokyo.

The culture media used are given in Table 1.

Estimation of lytic activity. Two methods were used to test the lytic activity.

Table 1. Media for algal and bacterial culture.

\begin{tabular}{lll}
\hline \multicolumn{2}{l}{ Organism } & \multicolumn{1}{c}{ Media } \\
\hline Blue-green algae & Modified Detmer's medium (12) \\
Other algae & Chlorella & Bristol's medium (13) \\
& Hormidium & Bristol's medium (13) \\
& Scenedesmus & Bristol's medium (13) \\
Zoochlorella & Bristol's medium (13) \\
Trebouxia & Bristol's medium enriched with 1\% glucose (13) \\
Navicula & Tsujii's medium (12) \\
Euglena & Tsubo's medium (12) \\
Bacteria & Trypticase soy agar (Difco) \\
Fungi & Malt-yeast extract medium (14)
\end{tabular}

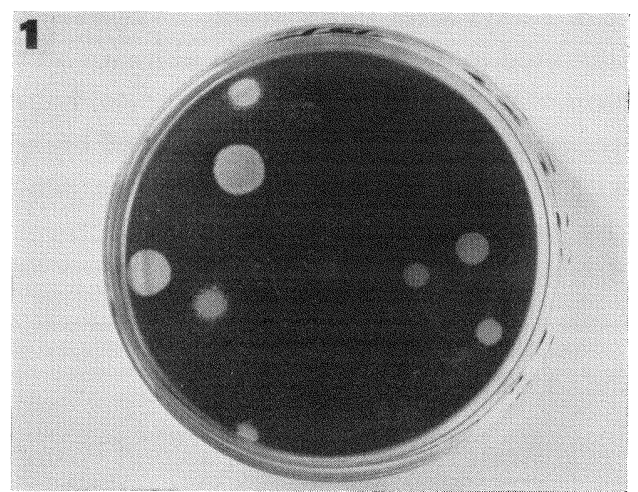

Fig. 1. Plaques formed by lytic bacterium MY-1 on lawns of Anabaena cylindrica.

Fig. 2. Longitudinal section of lytic bacterium MY-1. Glutaraldehyde-permanganate fixation. $0.5 \mu \mathrm{m}$.

$\mathrm{M}$; mesosome. The marker indicates

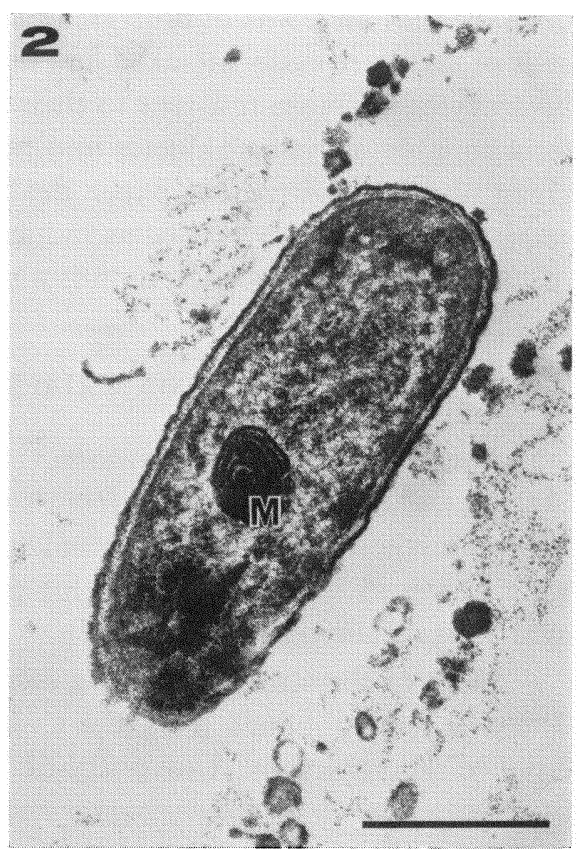


In the first method, a loop of algae-lysing bacteria was inoculated on algal or bacterial lawn and the development of lytic zone was inspected every day. In the second method, appearance of plaques was examined by the soft-agar overlayer technique (11).

Electron microscopy. The algae, after inoculation of the bacteria, were prefixed for $1 \mathrm{hr}$ at $4^{\circ}$ with $4 \%$ glutaraldehyde in $0.1 \mathrm{~m}$ cacodylate buffer, $\mathrm{pH} \mathrm{7.4.}$ After washing, they were fixed with $1 \% \mathrm{OsO}_{4}$ for $3 \mathrm{hr}$ at $4^{\circ}$ or with $2 \% \mathrm{KMnO}_{4}$ (aqueous, unbuffered) for $3 \mathrm{hr}$ at $4^{\circ}$ and embedded in $1 \%$ agar. The agar blocks cut into small pieces were embedded in epoxy resin (15). The block was sectioned with a diamond knife in LKB Ultrotome III. Thin sections were successively stained with $2 \%$ uranyl acetate for $90 \mathrm{~min}$ and with lead citrate for about $10 \mathrm{~min}$, and were examined with a Hitachi HU-11B electron microscope operated at $75 \mathrm{kV}$.

\section{RESULTS AND DISCUSSION}

Isolation and characterization of algae-lysing bacteria

The bacteria were isolated from soil samples collected in Africa and Japan.
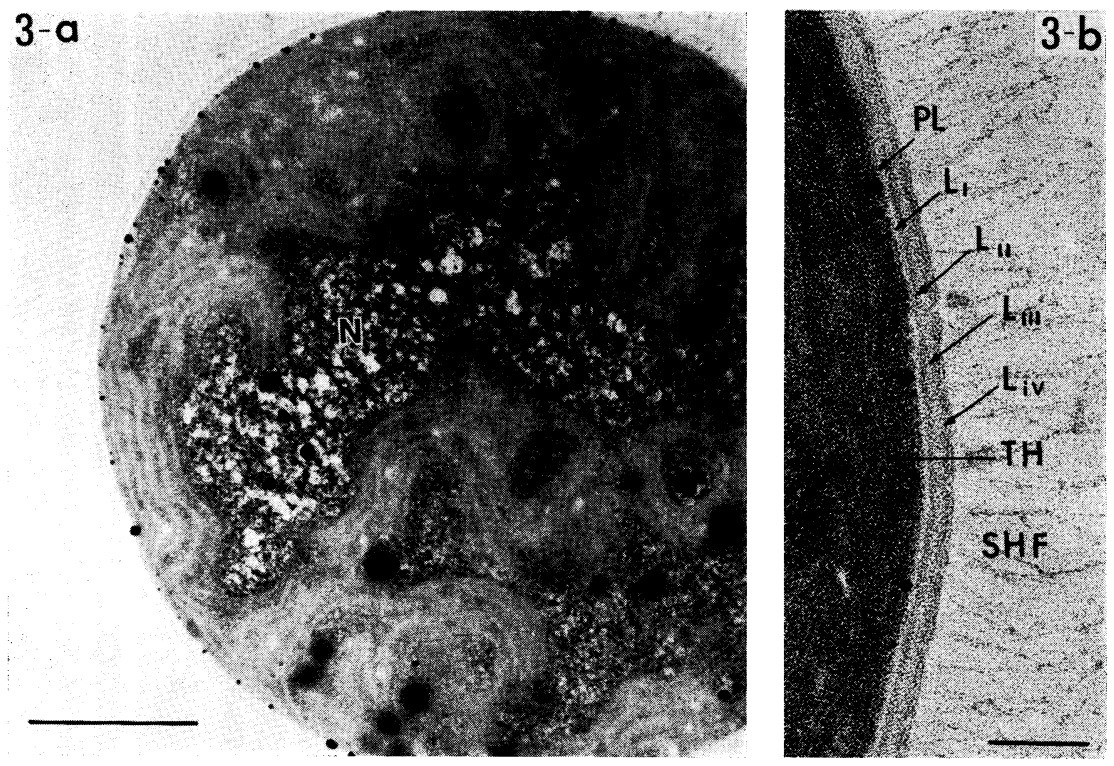

Fig. 3a. Intact vegetative cell of Anabaena cylindrica.

The figure shows fibrous nature of the sheath. Glutaraldehyde-osmium fixation. The marker indicates $0.5 \mu \mathrm{m}$.

Fig. 3b. Higher magnification of sheath fibers and cell wall layers.

Sources same as Fig. 3a. $\mathrm{L}_{\mathrm{I}-\mathrm{IV}}$, layers of the cell wall; SHF, sheath fiber; PL, plasmalemma; $\mathrm{TH}$, thylakoid membrane; $\mathrm{N}$, nuclear region. The marker indicates $0.1 \mu \mathrm{m}$. 
They grow on lawns of living cells of blue-green algae (Fig. 1). They hardly grew in bacterial liquid media. Bacterial colonies on the lawn of blue-green algae became visible 2-3 days after inoculation and plaques were produced after 5-6 days. These bacteria were gram-negative rods $(0.4 \sim 0.8 \times 1.5 \sim 4.5 \mu \mathrm{m})$ and produced an orange pigment. Among them, one clone of bacterium was selected. For reference, it was named bacterium MY-1. No flagella were observed in electron micrography. The bacterial cell contained a mesosome (Fig. 2). The characteristics exhibited by the present bacterium were similar to those of members of Myxobacterales reported by DafT and Stewart $(6,9)$, Shilo (4), Stewart and Brown $(3,5,8)$, and Wu et al. (2). The presence of mesosomes has also been reported in some other myxobacters, Chondrococcus columnaris (16) and Myxococcus xanthus (17).

\section{Host range of algae-lysing bacteria}

Most of the Cyanophyta tested were lysed rapidly by bacterium MY-1 although all members of the family Stigonematales and several other strains were nonsusceptible. Green algae, diatoms, some bacteria, and fungi were also not lysed (Table 2). The host range of bacterium MY-1 was wider than that of cyanophages $(18-21)$.

Table 2. Host range of lytic activity of bacterium MY-1.

\begin{tabular}{|c|c|c|}
\hline Organism & & Lytic activity \\
\hline \multicolumn{3}{|l|}{ Blue-green algae } \\
\hline \multicolumn{3}{|c|}{ Chroococcales } \\
\hline \multicolumn{3}{|c|}{ Chroococcaceae } \\
\hline & Anacystis marina $(\mathrm{M}-122)$ & + \\
\hline & Anacystis nidulans $(\mathrm{M}-6)$ & + \\
\hline & Gloeocapsa alpicola (M-123) & + \\
\hline \multicolumn{3}{|l|}{ Nostocales } \\
\hline \multicolumn{3}{|c|}{ Oscillatoriaceae } \\
\hline & Borzia trilocularis (M-117) & + \\
\hline & Lyngbya borgerti $(\mathrm{M}-9)$ & + \\
\hline & Lyngbya aerugineo-coerulea $(\mathrm{M}-12)$ & - \\
\hline & Lyngbya langerheimii $(\mathrm{M}-11)$ & + \\
\hline & Microcoleus paludosus (M-134) & + \\
\hline & Oscillatoria amoena $(\mathrm{M}-18)$ & + \\
\hline & Oscillatoria animalis $(\mathrm{M}-75)$ & + \\
\hline & Oscillatoria mougeotii $(\mathrm{M}-72)$ & - \\
\hline & Oscillatoria neglecta $(\mathrm{M}-19,74,82,83)$ & + \\
\hline & Oscillatoria numidica $(\mathrm{M}-96)$ & + \\
\hline & Oscillatoria laetevirens (M-42) & + \\
\hline & Oscillatoria laetevirens (M-106) & - \\
\hline & Oscillatoria tenuis $(\mathrm{M}-20,60)$ & + \\
\hline & Oscillatoria tenuis $(\mathrm{M}-50)$ & - \\
\hline & Oscillatoria sp. (M-51, W-1, 15, 18, $22,25,30)$ & + \\
\hline & Oscillatoria subbrevis $(\mathrm{M}-64)$ & - \\
\hline
\end{tabular}


Table 2. (Contd.)

\begin{tabular}{|c|c|c|}
\hline Organism & & Lytic activity \\
\hline & Phormidium ambigium (M-89, 91, 93, 94, 107) & + \\
\hline & Phormidium ambigium (M-71, $76,80,87,90)$ & \pm \\
\hline & Phormidium ambigium $(\mathrm{M}-73,108)$ & 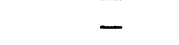 \\
\hline & Phormidium angustissimum (M-21) & + \\
\hline & Phormidium autumnale (M-22) & + \\
\hline & Phormidium foveolarum $(\mathrm{M}-43,59,66,68,78)$ & + \\
\hline & Phormidium foveolarum (M-112) & - \\
\hline & Phormidium henningsii (M-88) & - \\
\hline & Phormidium jadinianum $(\mathrm{M}-62,81)$ & + \\
\hline & Phormidium jadinianum (M-45) & - \\
\hline & Phormidium luridum $(\mathrm{M}-84,99)$ & + \\
\hline & Phormidium molle (M-77) & - \\
\hline & Phormidium papyraceum (M-28) & + \\
\hline & Phormidium subfuscum (M-24) & + \\
\hline & Phormidium tenue (M-25, 40, 85, 95, 111, 113) & + \\
\hline & Shizothrix calcicola & + \\
\hline & Symploca muscorum & + \\
\hline \multicolumn{3}{|l|}{ Nostocaceae } \\
\hline & Anabaena catenula (M-119) & - \\
\hline & Anabaena cylindrica $(\mathrm{M}-1)$ & + \\
\hline & Anabaena variabilis $(\mathrm{M}-2,3,58)$ & + \\
\hline & Anabaenopsis circularis $(\mathbf{M}-4,5)$ & + \\
\hline & Aulosira fertilissima (M-126, 128) & + \\
\hline & Chlorogloea fritschii $(\mathrm{M}-127)$ & - \\
\hline & Cylindrosperumum muscicola (M-32) & + \\
\hline & Fremyella diplosiphon $(\mathrm{M}-100)$ & + \\
\hline & Nostoc commune (M-13) & + \\
\hline & Nostoc commune (M-115) & - \\
\hline & Nostoc carneum (M-35) & + \\
\hline & Nostoc linckia $(\mathbf{M}-30)$ & + \\
\hline & Nostoc muscorum (M-14) & + \\
\hline & Nostoc punctiforme (M-15) & + \\
\hline & Nostoc sp. (M-16, 17, 27, 31, 46, 47, 54) & + \\
\hline & Palmoglea protuberans (M-116) & - \\
\hline \multicolumn{3}{|l|}{ Rivulariaceae } \\
\hline & Calothrix brevissima $(\mathrm{M}-7,34,37)$ & + \\
\hline & Calothrix brevissima $(\mathrm{M}-38)$ & \pm \\
\hline & Calothrix elenkinii (M-61) & + \\
\hline & Calothrix gracillis $(\mathrm{M}-55,56)$ & + \\
\hline & Calothrix membranacea (M-97) & + \\
\hline & Calothrix parientina $(\mathrm{M}-121)$ & + \\
\hline \multicolumn{3}{|c|}{ Scytonemataceae } \\
\hline & Plectonema boryanum (M-118) & + \\
\hline & Plectonema boryanum (M-101) & - \\
\hline & Plectonema calothricoides (M-120) & + \\
\hline & Plectonema notatum $(\mathrm{M}-36)$ & + \\
\hline & Plectonema tenue (M-63) & + \\
\hline
\end{tabular}


Table 2. (Contd.)

\begin{tabular}{|c|c|c|}
\hline Organism & & Lytic activity \\
\hline & Scytonema schidlei (M-33) & + \\
\hline & Scytonema sp. (M-65, W-19) & + \\
\hline & Scytonematopsis sp. (W-5, 6, 7, 17, 21) & + \\
\hline & Tolypothrix distorta (M-98) & - \\
\hline & Tolypothrix distorta (M-52) & + \\
\hline & Tolypothrix tenuis $(\mathrm{M}-29,39,57)$ & + \\
\hline & Tolypothrix tenuis $(\mathrm{M}-70,110)$ & \pm \\
\hline \multicolumn{3}{|c|}{ Stigonematales } \\
\hline & Fischerella muscicola (M-125) & - \\
\hline & Fischerella sp. (W-2, 3, 29) & - \\
\hline \multicolumn{3}{|c|}{ Other algae, bacteria and fungi } \\
\hline & Chlorella ellipsoidea (C-27) & - \\
\hline & Chlorella pyrenoidosa $(\mathrm{C}-28)$ & - \\
\hline & Chlorella vulgaris $(\mathrm{C}-150)$ & - \\
\hline & Hormidium flaccidum (C-164) & - \\
\hline & Scenedesmus obliquus (C-72) & - \\
\hline & Trebouxia erici (C-116) & - \\
\hline & Zoochlorella parasitica $(\mathrm{C}-201)$ & - \\
\hline & Navicula zonata & - \\
\hline & Euglena gracilis $(\mathrm{E}-3)$ & - \\
\hline & Bacillus subtilis & - \\
\hline & Escherichia coli & - \\
\hline & Pseudomonas aeruginosa $\left(\mathrm{Ps}_{-}-2,8\right)$ & - \\
\hline & Staphylococcus aureus & - \\
\hline & Saccharomyces sake & - \\
\hline & Saccharomyces cereviciae & - \\
\hline
\end{tabular}

+ , susceptible; -, resistant; \pm , not clear.

Ultrastructure of the intact and infected cells

In vegetative cells of Anabaena cylindrica, thylakoids (TH), nucleoplasmic region $(\mathrm{N})$, plasmalemma $(\mathrm{PL})$, cell wall composed of four layers $\left(\mathrm{L}_{\mathrm{I}-\mathrm{IV}}\right)$, and sheath fiber (SHF) were seen (Figs. 3 a and 3 b) (22). The cells infected with bacteria are distinguishable from intact cells. In the early stage of infection, sheath fiber and cell walls of the vegetative cells disappeared, but the thylakoid membranes remained (Fig. 4). In the later stage of infection, only membranous materials, probably fragments of thylakoid, were left (Fig. 5).

In the intact heterocysts, structures of thick wall envelopes were observed (Fig. 6) (23). When observed with a light microscope, heterocysts infected by bacterium MY-1 appeared to be intact. However, intrusion of the bacterium into the heterocyst was clearly demonstrated by electron microscopy (Figs. 7, 8). The bacteria probably penetrate into the cell through a pore channel of the heterocyst, and attack plasmalemma and some part of the cell wall (Fig. 7). In the later stages of lysis, membrane structure in the heterocyst was fully digested and only 

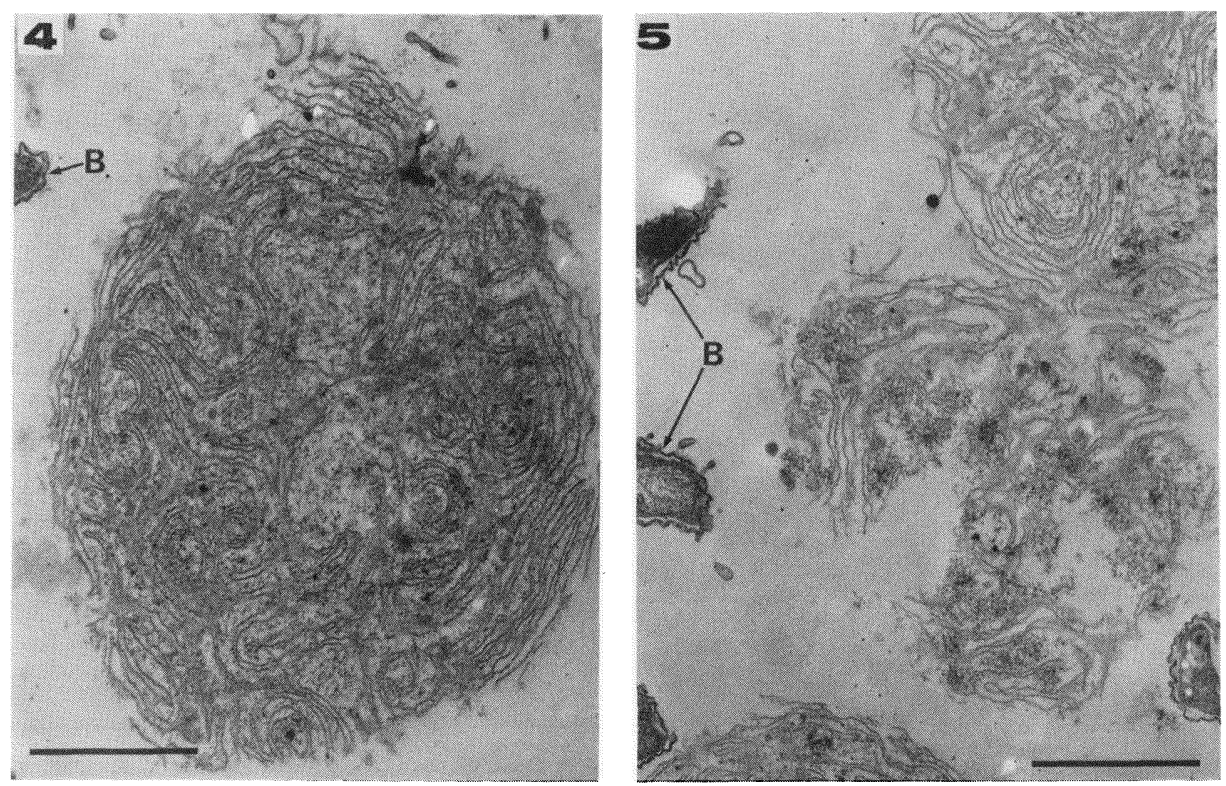

Fig. 4. Vegetative cell of Anabaena cylindrica in the early stage of infection with bacteria.

The figure shows loss of the sheath fiber and the outer layers of cell walls. B, Bacterium. Glutaraldehyde-osmium fixation. The marker indicates $1 \mu \mathrm{m}$.

Fig. 5. Vegetative cell of Anabaena cylindrica in the last stage of infection.

Complex membranous materials only remain. Glutaraldehyde-osmium fixation. The marker indicates $1 \mu \mathrm{m}$.

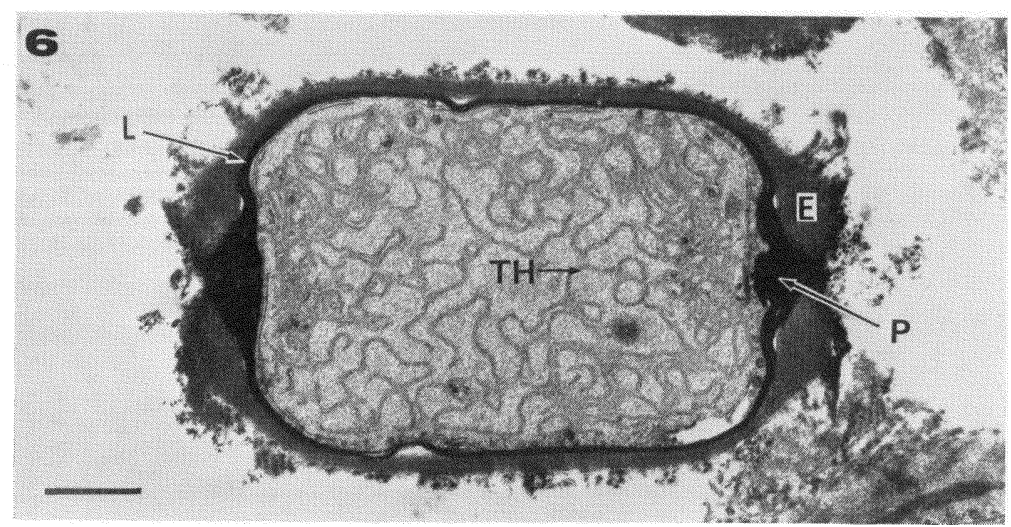

Fig. 6. Intact heterocyst of Anabaena cylindrica.

E, envelope; L, laminated layer of envelope; P, pore channel; TH, thylakoid membrane. Permanganate fixation. The marker indicates $1 \mu \mathrm{m}$. 

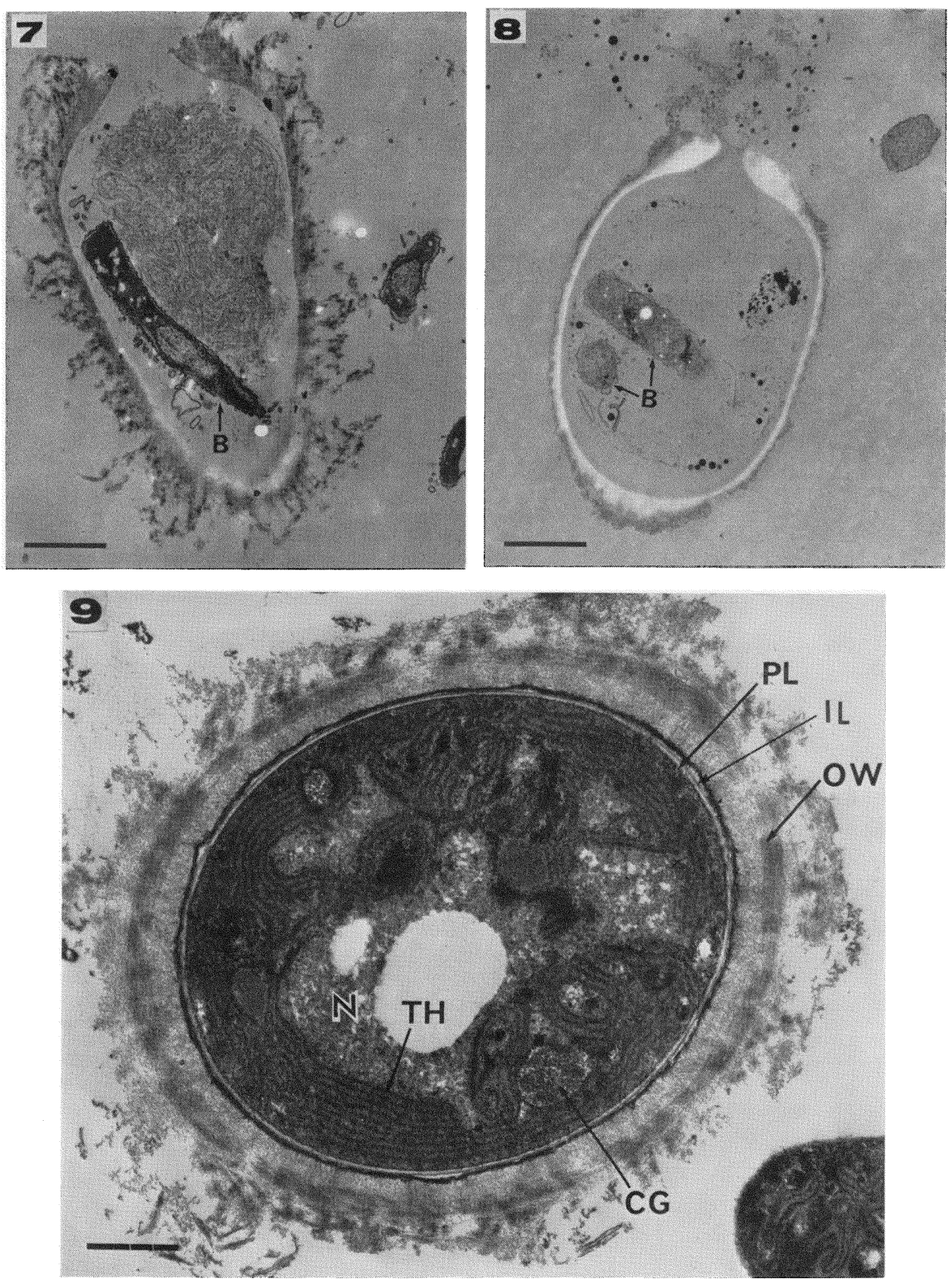

Fig. 7. Heterocyst of Anabaena cylindrica in the early stage of infection with bacteria.

Note the presence of bacterium within heterocyst. The inner layer of the cell walls and plasmalemma were already lost. B, bacterium. Glutaraldehyde-osmium fixation. The marker indicates $1 \mu \mathrm{m}$. 


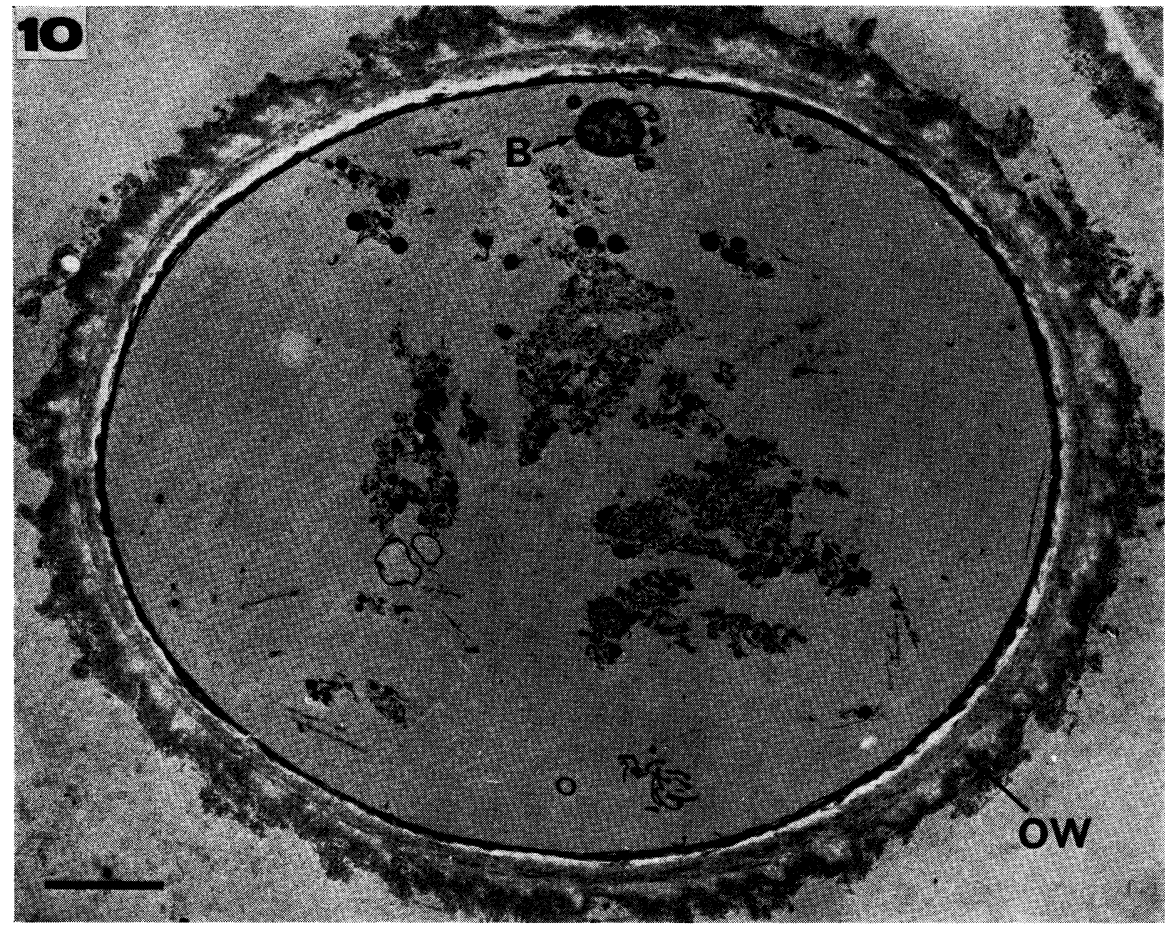

Fig. 10. Akinete of Anabaena cylindrica in the later stage of infection with bacteria. OW, outer wall; B, bacterium. Glutaraldehyde-osmium fixation. The marker indicates $1 \mu \mathrm{m}$.

their wall envelopes remained (Fig. 8).

Similar results were also observed in the case of akinetes. The intact akinetes are surrounded with thick dense fibrous envelopes and include cyanophycin granules in the cytoplasm (Fig. 9) (24). The bacterium penetrated into akinete attacked inner layers and cytoplasmic regions (Figs. 10,11). The outer wall remained intact as was the case with heterocysts.

The different responses to the action of the bacterium can be attributed to the differences in the cell wall composition of akinetes, heterocyst, and vegetative cells (25).

The plaques that formed by bacterium MY-1 were similar to viral plaques in appearance (Fig. 1) (18). However, the observation with electron microscope

Fig. 8. Heterocyst of Anabaena cylindrica in the later stage of infection.

B, bacterium. Glutaraldehyde-osmium fixation. The marker indicates $1 \mu \mathrm{m}$.

Fig. 9. Intact akinete of Anabaena cylindrica.

OW, outer wall; IL, inner layer; PL, plasmalemma; N, nuclear region; TH, thylakoid membrane; CG, cyanophycin granule. Permanganate fixation. The marker indicates $1 \mu \mathrm{m}$. 


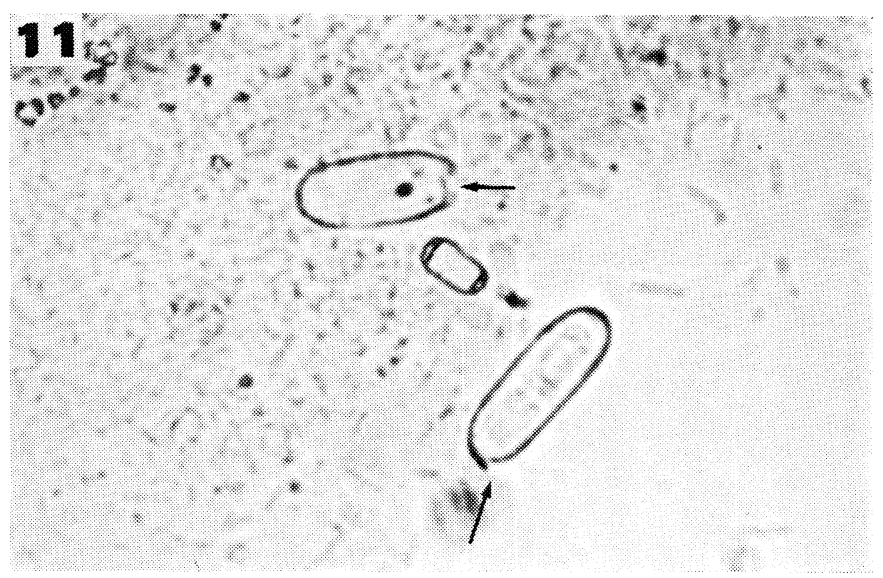

Fig. 11. Light micrograph of akinetes of Anabaena cylindrica attacked by bacterium MY-1. Most of akinetes show an opening at one end of envelopes (arrows) $(\times 1,200)$.

presented quite a different picture between the mode of lysis by bacteria and by virus. The algal cells infected by the cyanophage lysed when the mature virus were released into the surrounding medium (26-28). On the other hand, lysis induced by bacterium MY-1 occurred only when there was a direct contact between these bacteria and algae (Figs. 4, 5, 7, 8, and 10).

A short report by STEWART and Brown (5) states that a myxobacter, Cytophaga N-5, lyses akinetes and heterocysts as well as vegetative cells. Photosynthetic lamellae appear to be more resistant. However, the host range of lytic activity of our bacterium is different from that of Cytophaga $\mathrm{N}-5$.

We thank Professor A. Hattori, Ocean Research Institute, University of Tokyo, for his advice and encouragement during this research.

\section{REFERENCES}

1) M. SHILO, Bacteriol. Rev., 31, 180 (1967).

2) B. Wu, M. K. Hamdy, and H. B. Howe, Bacteriol. Proc., 48 (1968).

3) J. R. Stewart and R. M. Brown, Science, 164, 1523 (1969).

4) M. SHILo, J. Bacteriol., 104, 453 (1970).

5) J. R. Stewart and R. M. Brown, Bacteriol. Proc., 18 (1970).

6) M. J. Daft and W. D. P. Stewart, New Phytol., 70, 810 (1971).

7) M. ShILo, Mitt. Int. Ver. Limnol., 19, 206 (1971).

8) J. R. Stewart and R. M. Brown, Arch. Mikrobiol., 80, 176 (1971).

9) M. J. Daft and W. D. P. Stewart, New Phytol., 72, 799 (1973).

10) B. V. Gromov, O. G. Ivanov, K. A. Mamkaeva, and I. A. Avilov, Microbiology (USSR), 41, 952 (1973).

11) R. S. Safferman and M. E. Morris, J. Bacteriol., 88, 771 (1964).

12) A. Watanabe, J. Gen. Appl. Microbiol., 6, 283 (1960).

13) R. C. Starr, Am. J. Bot., 51, 1013 (1964). 
14) V. G. Lilly and H. L. Barnett, "Physiology of Fungi," McGraw-Hill, New York (1951), p. 464.

15) J. H. LufT, J. Biophys. Biochem. Cytol., 9, 409 (1961).

16) J. L. Pate and E. J. Ordal, J. Cell Biol., 35, 1 (1967).

17) H. Voelz, Arch. Mikrobiol., 51, 60 (1965).

18) R. S. SAfFerman and M. E. Morris, Science, 140, 679 (1963).

19) R. S. Safferman, M. E. Morris, L. A. Sherman, and R. Haslkorn, Virology, 39, 775 (1969).

20) R. S. Safferman, I. R. Schneider, R. L. Sleere, M. E. Morris, and T. O. Diener, Virology, 37, 386 (1969).

21) K. W. AdOlPh and R. HASELKorn, Virology, 46, 200 (1971).

22) L. V. LEAK, J. Ultrastruct. Res., 20, 190 (1967).

23) P. Fay and N. J. LANG, Proc. R. Soc. London B, 178, 185 (1971).

24) D. C. Wildon and F. V. Mercer, Arch. Mikrobiol., 47, 19 (1963).

25) J. H. Dunn and C. P. Wolk, J. Bacteriol., 103, 153 (1970).

26) K. M. Smith, R. M. Brown, Jr., P. L. Walne, and D. A. Goldstein, Virology, 30, 182 (1966).

27) R. M. Brown, Jr., K. M. Smith, and P. L. WANE, Nature (London), 212, 729 (1966),

28) K. M. Smith and R. M. Brown, Jr., Virology, 31, 329 (1967). 